\title{
Long-Term Cultivation of Fruit Plantations Decreases Mineralization and Nitrification Rates in Calcareous Soil in the Karst Region in Southwestern China
}

\author{
Zhijie Shan ${ }^{1}$, Zhe Yin ${ }^{1}$, Hui Yang ${ }^{2,3} \mathbb{B}$, Changqing Zuo ${ }^{1}$ and Tongbin Zhu ${ }^{2,3, *(\mathbb{C})}$ \\ 1 State Key Laboratory of Simulation and Regulation of Water Cycle in River Basin, China Institute of Water \\ Resources and Hydropower Research, Beijing 100038, China; shanzhj@iwhr.com (Z.S.); \\ yinzhe-2002@163.com (Z.Y.); zuochq@sina.com (C.Z.) \\ 2 Key Laboratory of Karst Dynamics, MRL, Institute of Karst Geology, CAGS, Guilin 541004, China; \\ yanghui-kdl@karst.ac.cn \\ 3 International Research Centre on Karst, Under the Auspices of UNESCO, Guilin 541004, China \\ * Correspondence: zhutongbin@gmail.com; Tel.: +86-773-5837840; Fax: +86-773-5837845
}

Received: 4 November 2020; Accepted: 27 November 2020; Published: 29 November 2020

\begin{abstract}
Determination of rates of mineralization of organic nitrogen $(\mathrm{N})$ into ammonium- $\mathrm{N}$ $\left(\mathrm{NH}_{4}{ }^{+}-\mathrm{N}\right)$ and nitrification of $\mathrm{NH}_{4}{ }^{+}-\mathrm{N}$ into nitrate- $\mathrm{N}\left(\mathrm{NO}_{3}{ }^{-}-\mathrm{N}\right)$ could be used to evaluate inorganic $\mathrm{N}$ supply capacity, which, in turn, could guide $\mathrm{N}$ fertilizer application practices in crop cultivation systems. However, little information is available on the change of mineralization and nitrification in soils under fruit cultivation systems converted from forestlands in karst regions. In a ${ }^{15} \mathrm{~N}$-tracing study, inorganic $\mathrm{N}$ supply capacity in forest soils and three typical fruit crop soils under long-term cultivation was investigated, in addition to factors influencing the supply, in calcareous soils in the karst regions in southwestern China. Long-term fruit crop cultivation decreased soil organic carbon (SOC), total $\mathrm{N}$, and calcium concentrations, cation exchange capacity (CEC), water holding capacity (WHC), $\mathrm{pH}$, and sand content, significantly, but increased clay content. Compared to that of forests, long-term fruit crop cultivation significantly decreased mineralization and nitrification rates to $0.61-1.34 \mathrm{mg} \mathrm{N} \mathrm{kg}^{-1} \mathrm{~d}^{-1}$ and $1.95-5.07 \mathrm{mg} \mathrm{N} \mathrm{kg}^{-1} \mathrm{~d}^{-1}$, respectively, from $2.85-6.49 \mathrm{mg} \mathrm{N} \mathrm{kg}^{-1} \mathrm{~d}^{-1}$ and 8.17-15.5 $\mathrm{mg} \mathrm{N} \mathrm{kg}^{-1} \mathrm{~d}^{-1}$, respectively, but greatly increased the mean residence times of $\mathrm{NH}_{4}{ }^{+}-\mathrm{N}$ and $\mathrm{NO}_{3}{ }^{-}-\mathrm{N}$. The results indicate that long-term fruit crop cultivation could decrease soil inorganic $\mathrm{N}$ supply capacity and turnover in karst regions. Both mineralization and nitrification rates were significantly and positively correlated with SOC and total N concentrations, CEC, and WHC, but negatively correlated with clay content, suggesting that decreased soil organic matter and increased clay content were responsible for the decline in mineralization and nitrification rates in soils under long-term cultivation of fruit crops. The results of the present study highlight the importance of rational organic fertilizer application in accelerating soil inorganic $\mathrm{N}$ supply and turnover under long-term cultivation of fruit crops in karst regions.
\end{abstract}

Keywords: karst region; fruit crop; ${ }^{15} \mathrm{~N}$ tracing; mineralization; nitrification; inorganic $\mathrm{N}$ supply

\section{Introduction}

Karst geomorphology, which develops from carbonate rocks, is widely distributed on the Earth's surface and China accounts for $15.6 \%$ of the karst region in the world (more than 22 million $\mathrm{km}^{2}$ ), with the largest karst region (>1.9 million $\mathrm{km}^{2}$ ) found in southwestern China [1,2]. Because carbonate rocks (mainly limestone and dolostone) are easily dissolved by groundwater and rainwater, only relatively small remnants of such rocks remain [3,4]. Therefore, plateau mountains are extensively observed in karst regions, and they are characterized by thin soil layers, sink holes, and steep slopes [5-7]. 
In the karst region, the population density is high and arable land resources become severely limited, so that people often deforest sloping lands in such regions to plant common crops (e.g., corn, soybean); however, the economic benefits of such cropping systems are extremely low. In addition, such systems often induce negative effects in karst regions, such as large-scale "rocky desertification" [5-7]. Consequently, high-yield and economically sustainable fruit crops (e.g., citrus or pitaya) have been cultivated extensively in the karst region in China to boost farmers' incomes [3,7]. Notably, fruit crop production decreases markedly after long-term cultivation in such regions. Besides the impacts of management practices, decline in soil fertility is considered to be the key factor negatively affecting crop growth [8-10]. Thus, investigating soil nutrient availability to evaluate soil fertility could guide fruit crop cultivation in lands converted from forests or woodlands in karst regions.

Nitrogen $(\mathrm{N})$ is an essential element limiting soil fertility and plant growth in terrestrial ecosystems [11,12]. Although crops can directly utilize low-molecular weight organic $\mathrm{N}$, ammonium-N $\left(\mathrm{NH}_{4}{ }^{+}-\mathrm{N}\right)$ and nitrate- $\mathrm{N}\left(\mathrm{NO}_{3}{ }^{-}-\mathrm{N}\right)$, two inorganic $\mathrm{N}$ pools, are still the main $\mathrm{N}$ forms absorbed by plants $[13,14]$. Nitrogen in soil exists mainly in organic form, which needs to be first converted into $\mathrm{NH}_{4}{ }^{+}-\mathrm{N}$ through mineralization, followed by the oxidation of $\mathrm{NH}_{4}{ }^{+}-\mathrm{N}$ into $\mathrm{NO}_{3}{ }^{-}-\mathrm{N}$ through nitrification. Therefore, inorganic $\mathrm{N}$ supply in soil is primarily controlled by mineralization and nitrification processes $[15,16]$, and inorganic $\mathrm{N}$ supply capacity can be assessed by the determination of mineralization and nitrification rates. Considering the essential role of inorganic $\mathrm{N}$ in plant growth and development, and ecological status, mineralization and nitrification processes and the factors influencing them have attracted considerable attention in natural and agricultural ecosystems [17-20]; however, most studies have been conducted in non-karst regions and the relevant information for karst regions is very limited [21,22].

In karst regions, the main soil types are calcareous soils developed from carbonate rock, which are characterized by high $\mathrm{pH}$, high calcium (Ca), and limited acid-insoluble residues in limestone and dolostone $[3,23,24]$, which can cause the obvious difference in $\mathrm{N}$ cycling in calcareous soils and other soil types. Previous studies have reported that soil organic matter is the critical factor affecting mineralization, which is positively correlated with organic carbon $(\mathrm{C})$ and total $\mathrm{N}$ concentrations $[16,18,25]$. High Ca content in calcareous soil can bind with organic matter to enhance its accumulation [26,27]; however, the conversion of forestland into agricultural plantations significantly decreases soil organic matter [10,19], which suggests a possible decline in mineralization rate as the substrates decrease. In addition, high amounts of organic and inorganic $\mathrm{N}$ fertilizers are often applied during the conversion of forestland into cropland, which can considerably stimulate the oxidation of $\mathrm{NH}_{4}{ }^{+}-\mathrm{N}$ into $\mathrm{NO}_{3}{ }^{-}-\mathrm{N}$ by increasing the abundance and activity of ammonia-oxidizing microorganisms, e.g., ammonia-oxidizing archaea (AOA) and ammonia-oxidizing bacteria (AOB) [28,29]. However, such stimulatory effects may not be observed in calcareous soils under long-term fruit crop cultivation. At the initial stages of formation of calcareous soils, acid-insoluble matter resulting from carbonate rock is limited and soil is clayey $[3,30]$. Under undisturbed natural ecosystems, high organic matter can stimulate the formation of macroaggregate fractions and improve soil structure, which can stimulate the oxidation of $\mathrm{NH}_{4}{ }^{+}-\mathrm{N}$ into $\mathrm{NO}_{3}{ }^{-}-\mathrm{N}$ under high $\mathrm{pH}$ conditions [10]. However, calcareous soils may become clayey again due to the decreased organic matter following long-term agricultural cultivation in karst regions $[3,7]$, which could inhibit nitrification and the turnover of inorganic $\mathrm{N}$ severely even though the soil $\mathrm{pH}$ is high. Therefore, we hypothesized that long-term fruit-crop cultivation converted from forestland would significantly (1) decrease inorganic N supply capacity through the inhibition of mineralization and nitrification, and (2) decrease inorganic $\mathrm{N}$ turnover in calcareous soil in karst regions.

To verify our hypotheses, typical fruit crop systems under long-term cultivation ( $>7$ years) were sampled in karst regions of southwestern China. Mineralization and nitrification rates were determined using a ${ }^{15} \mathrm{~N}$-tracing method to evaluate the inorganic $\mathrm{N}$ supply capacity and turnover in calcareous soils. In addition, other indicators related to soil quality were determined to analyze the major factors influencing mineralization and nitrification rates. 


\section{Materials and Methods}

\subsection{Site Description and Sample Collection}

Three typical fruit plantations, including citrus (Citrus sinesis L. Osbeck), pitaya (Hylocereus undatus) and "Shatangju" (Citrus reticulata Blanco) plantations, were selected in three karst regions of southwest China (Figure 1). Adjacent forests were selected as the controls.

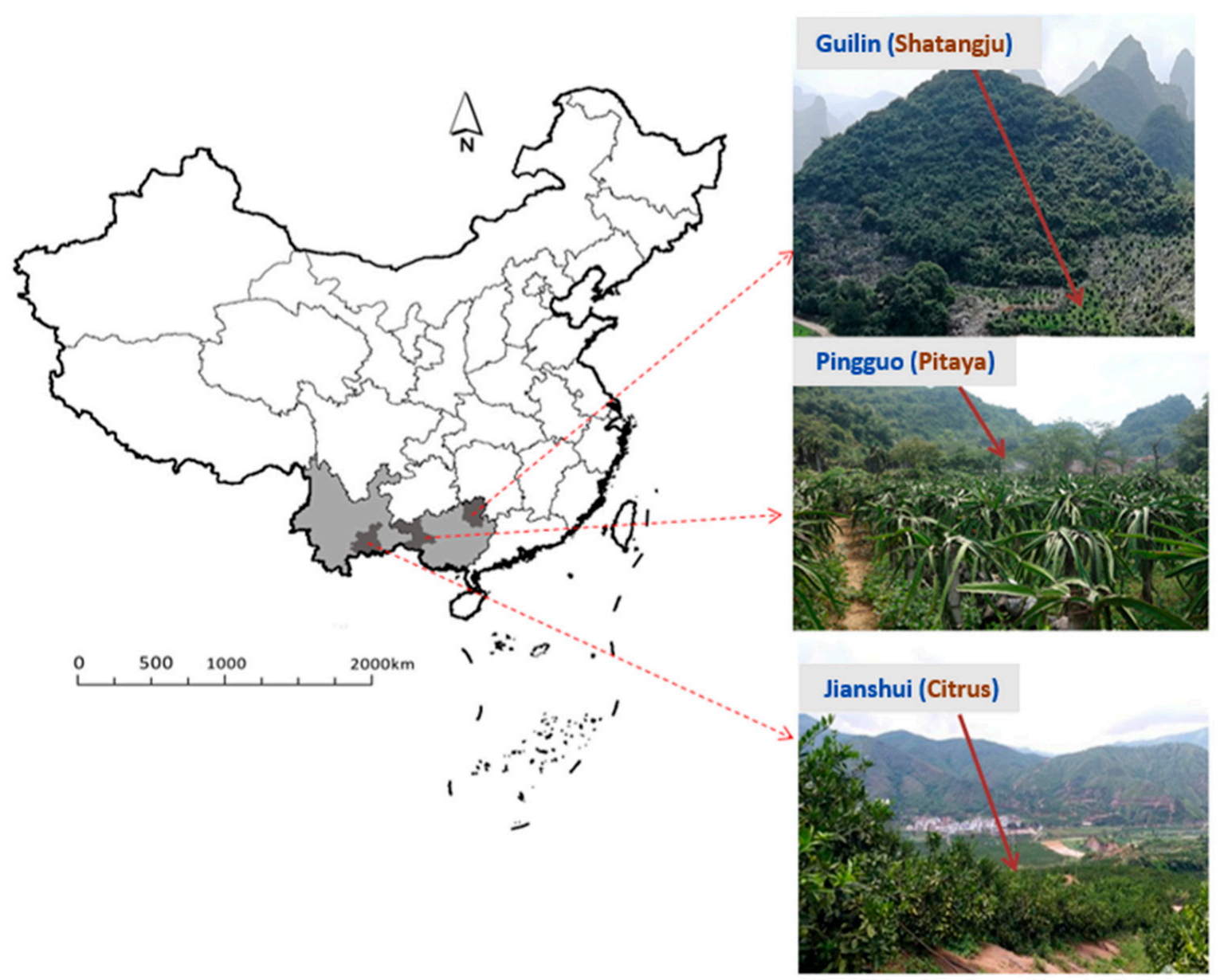

Figure 1. Location of three regions studied in the karst region of southwest China.

Citrus plantations examined in the present study were cultivated at the Jianshui Karst Field Research Station (102 $54^{\prime} 12^{\prime \prime}$ E, 23 $\left.37^{\prime} 13^{\prime \prime} \mathrm{N}\right)$, located in Jianshui city, Yunnan Province. The region has a subtropical monsoon climate, and the mean annual precipitation, evaporation, and temperature are $805 \mathrm{~mm}, 2297 \mathrm{~mm}$, and $19.8^{\circ} \mathrm{C}$, respectively. The citrus trees were under cultivation for more than 8 years, with a tree spacing of $3 \times 4 \mathrm{~m}$ and a planting density of approximately 800 trees ha $^{-1}$. Approximately 480,320 , and $320 \mathrm{~kg} \mathrm{ha}^{-1} \mathrm{y}^{-1}$ of $\mathrm{N}, \mathrm{P}_{2} \mathrm{O}_{5}$, and $\mathrm{K}_{2} \mathrm{O}$, respectively, were applied to the citrus plantations. The dominant tree species in the adjacent forests are Quercus cocciferoides Hand.-Mazz., Fraxinus malacophylla Hemsl. and Pittosporum brevicalyx (Oliv.) Gagnep. The slope position, slope, and elevations of sample sites were middle slope, $8.52^{\circ}-10.2^{\circ}$, and $1378-1410 \mathrm{~m}$, respectively, and the type of soil is calcareous Alfisol (WRB Soil Taxonomy).

Pitaya plantations examined were cultivated at the Guohua Karst Experimental Station $\left(107^{\circ} 25^{\prime} 20^{\prime \prime}\right.$ E, $\left.23^{\circ} 24^{\prime} 50^{\prime \prime} \mathrm{N}\right)$, located in Pingguo county, Guangxi Province. The region has a subtropical monsoon climate, and the mean annual precipitation, evaporation, and temperature are $1572 \mathrm{~mm}$, $1557 \mathrm{~mm}$, and $21.0^{\circ} \mathrm{C}$, respectively, and the crop was under cultivation for more than 10 years. Pitaya pillars had a spacing of $3 \times 3 \mathrm{~m}$, with approximately 6675 trees ha $^{-1}$. Approximately 260, 210, 195, 
and $12,210 \mathrm{~kg} \mathrm{ha}^{-1} \mathrm{y}^{-1}$ of $\mathrm{N}, \mathrm{P}_{2} \mathrm{O}_{5}, \mathrm{~K}_{2} \mathrm{O}$, and sheep manure (including $6.5 \mathrm{~g} \mathrm{TN} \mathrm{kg}^{-1}, 5.0 \mathrm{~g} \mathrm{TP} \mathrm{kg}^{-1}$, $3.0 \mathrm{~g} \mathrm{TK} \mathrm{kg}^{-1}$ ), respectively, were applied to pitaya fields. The dominant tree species in the forest adjacent to the pitaya plantation are Zenia insignis Chun, Melia azedarach L., Apodytes dimidiate E. Mey. ex Arn. and Choerospondias axillaris (Roxb.) Burtt et Hill. The slope position, slope, and elevation of sample sites were middle, $14.3^{\circ}-19.8^{\circ}$, and $308-420 \mathrm{~m}$, respectively, and the soil type in the region is calcareous Cambisols (WRB Soil Taxonomy).

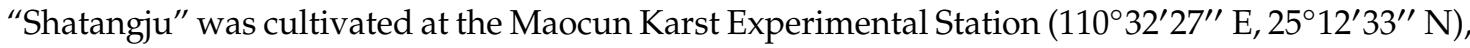
located in the southeast of Guilin City, Guangxi Province. The region has a subtropical monsoon climate, and the mean annual precipitation, evaporation, and temperature are $1980 \mathrm{~mm}, 1459 \mathrm{~mm}$, and $18.6^{\circ} \mathrm{C}$, respectively. The "Shatangju" plantation examined was under cultivation for more than 7 years. The plant spacing was $3 \times 4 \mathrm{~m}$, at a density of approximately 930 trees $\mathrm{ha}^{-1}$. Approximately 306, 186, 214 , and $1250 \mathrm{~kg} \mathrm{ha}^{-1} \mathrm{y}^{-1}$ of $\mathrm{N}, \mathrm{P}_{2} \mathrm{O}_{5}, \mathrm{~K}_{2} \mathrm{O}$, and sheep manure (including $5.1 \mathrm{~g} \mathrm{TN} \mathrm{kg}^{-1}, 5.5 \mathrm{~g} \mathrm{TP} \mathrm{kg}^{-1}$, $3.5 \mathrm{~g} \mathrm{TK} \mathrm{kg}^{-1}$ ), respectively, were applied to the pitaya field. The dominant tree species in the forest adjacent to the citrus plantation are Loropetalum chinense (R. Br.) Oliv., Cyclobalanopsis glauca (Thunb.) Oerst. and Vitex negundo L. The slope position, slope, and elevation of sample sites were middle, $15.6^{\circ}-23.2^{\circ}$, and $198-229 \mathrm{~m}$, respectively, and the soil type in the region is calcareous Alfisol (WRB Soil Taxonomy).

In each region, three representative sites were selected in each forest and in each fruit crop plantation as the spatial replicates. The distances between sites were $>300 \mathrm{~m}$, and three plots $(1.0 \times 1.0 \mathrm{~m})$ at each site were selected randomly at $20 \mathrm{~m}$ intervals. After removing plant residues, two soil cores ( $5 \mathrm{~cm}$ diameter) were obtained at a depth of $0-15 \mathrm{~cm}$ in each plot. Subsequently, all subsamples were mixed to form a composite sample for each site, yielding three forest soil and three fruit crop soil samples in each region. Fresh soil was passed through a $2 \mathrm{~mm}$ sieve and stones and roots removed to improve soil homogeneity. One part was dried for using in the determination soil basic physicochemical properties, and the other part was immediately stored at $4{ }^{\circ} \mathrm{C}$ for use in the determination of mineralization and nitrification rates.

\section{2. ${ }^{15} \mathrm{~N}$-Tracing Experiment}

The ${ }^{15} \mathrm{~N}$ labeling experiments with two ${ }^{15} \mathrm{~N}$ treatments $\left({ }^{15} \mathrm{NH}_{4} \mathrm{NO}_{3}\right.$ and $\mathrm{NH}_{4}{ }^{15} \mathrm{NO}_{3}$ at 10 atom\% excess) and three replicates per treatment were performed in the laboratory. For each soil sample, $30 \mathrm{~g}$ of fresh soil (oven-dried basis) was weighted into a $250 \mathrm{~mL}$ Erlenmeyer flask and preincubated for $24 \mathrm{~h}$ at $25{ }^{\circ} \mathrm{C}$. After the preincubation period, ${ }^{15} \mathrm{NH}_{4} \mathrm{NO}_{3}$ or $\mathrm{NH}_{4}{ }^{15} \mathrm{NO}_{3}$ solutions $(1 \mathrm{~mL})$ were applied evenly in the sample soils at a rate of $100 \mathrm{mg} \mathrm{N} \mathrm{kg}^{-1}\left(50 \mathrm{mg} \mathrm{N} \mathrm{kg}^{-1}\right.$ as $\mathrm{NH}_{4}{ }^{+}-\mathrm{N}$ and $\mathrm{NO}_{3}{ }^{-}-\mathrm{N}$, respectively). Soil moisture was adjusted to $60 \%$ water holding capacity (WHC) and flasks were covered with plastic films with small holes and incubated at $25^{\circ} \mathrm{C}$. Soils were extracted with $150 \mathrm{~mL}$ of $2 \mathrm{M} \mathrm{KCl}$ solution at 0.5 and $24 \mathrm{~h}$ after $\mathrm{NH}_{4} \mathrm{NO}_{3}$ application to determine the $\mathrm{NH}_{4}{ }^{+}$and $\mathrm{NO}_{3}{ }^{-}$ concentrations, and their respective ${ }^{15} \mathrm{~N}$ enrichments according to a previous method $[15,16]$ using a continuous-flow analyzer (Skalar, Breda, The Netherlands) and a Sercon Integra 2 Isotope Ratio Mass Spectrometer (Sercon Ltd., Crewe, UK), respectively.

\subsection{Analyses}

After removing carbonate with dilute hydrochloric acid $(\mathrm{HCl})$, soil organic $\mathrm{C}(\mathrm{SOC})$ and total $\mathrm{N}$ concentrations were analyzed using a Sercon Integra 2 Elemental Analyzer (Sercon Ltd.). Soil pH was determined using a 1:2.5 (w:v) soil: water mixture using a SevenExcellence $\mathrm{pH} / \mathrm{mV}$ and conductivity meter (Mettler Toledo, Columbus, OH, USA). Soil water holding capacity was determined by the gravimetric method after soil saturation in the laboratory using a cutting ring filled with $<2 \mathrm{~mm}$ air-dried soil to a bulk density, which was close to that determined in the fields. The concentrations of total $\mathrm{Ca}$, potassium $(\mathrm{K})$, and phosphorus $(\mathrm{P})$ in soil were determined using $\mathrm{X}$-ray fluorescence $(\mathrm{XRF})$ spectroscopy. Cation exchange capacity (CEC) was analyzed by the ammonium acetate method at $\mathrm{pH}$ 7.0 [31]. For textural analyses, soil samples $(<2 \mathrm{~mm})$ were pretreated with hydrogen peroxide $\left(\mathrm{H}_{2} \mathrm{O}_{2}\right)$ 
and $\mathrm{HCl}$ to remove organic material and carbonates, respectively, and subsequently sodium hydroxide $(\mathrm{NaOH})$ solution was added as a dispersion agent. All samples were then dispersed in an ultrasonic bath and the particle-size distribution (clay $(<2 \mu \mathrm{m})$, silt $(2-50 \mu \mathrm{m})$ and sand $(50-2000 \mu \mathrm{m})$ ) of the suspensions was determined using an LS-230 laser particle characterization analyzer (Beckman Coulter, Brea, CA, USA).

\subsection{Data and Statistical Analyses}

Gross mineralization rate $\left(\mathrm{M}_{\mathrm{Norg}}, \mathrm{mg} \mathrm{N} \mathrm{kg}^{-1} \mathrm{~d}^{-1}\right)$ and gross nitrification rate $\left(\mathrm{O}_{\mathrm{NH} 4}, \mathrm{mg} \mathrm{N} \mathrm{kg}^{-1} \mathrm{~d}^{-1}\right)$ were calculated based on changes in concentrations and atom \% of $\mathrm{NH}_{4}{ }^{+}-\mathrm{N}$ in ${ }^{15} \mathrm{NH}_{4} \mathrm{NO}_{3}$-labeled samples and $\mathrm{NO}_{3}{ }^{-}-\mathrm{N}$ in $\mathrm{NH}_{4}{ }^{15} \mathrm{NO}_{3}$-labeled samples between time 0 and $\mathrm{t}$, respectively, according to Kirkham and Bartholomew (1954) [32], as follows:

$$
\mathrm{M}_{\text {Norg }}=\frac{\left[\mathrm{NH}_{4}^{+}\right]_{0}-\left[\mathrm{NH}_{4}^{+}\right]_{\mathrm{t}}}{\mathrm{t}} \times \frac{\log \left(\frac{\mathrm{APE}_{0}}{\mathrm{APE}}\right)}{\log \frac{\left[\mathrm{NH}_{4}^{+}\right]_{0}}{\left[\mathrm{NH}_{4}^{+}\right]_{\mathrm{t}}}}
$$

where $\mathrm{t}$ is the incubation time (days); and $\left[\mathrm{NH}_{4}{ }^{+}\right]_{0}$ and $\left[\mathrm{NH}_{4}{ }^{+}\right]_{\mathrm{t}}$ are the $\mathrm{NH}_{4}{ }^{+}-\mathrm{N}$ concentrations $\left(\mathrm{mg} \mathrm{N} \mathrm{kg}^{-1}\right)$ at time 0 and $\mathrm{t}$, respectively. $\mathrm{APE}_{0}$ and $\mathrm{APE}_{\mathrm{t}}$ are the ${ }^{15} \mathrm{~N}$ atom $\%$ excess of $\mathrm{NH}_{4}{ }^{+}-\mathrm{N}$ at time 0 and $t$, respectively.

$$
\mathrm{O}_{\mathrm{NH}_{4}}=\frac{\left[\mathrm{NO}_{3}^{-}\right]_{0}-\left[\mathrm{NO}_{3}^{-}\right]_{\mathrm{t}}}{\mathrm{t}} \times \frac{\log \left(\frac{\mathrm{APE}_{0}}{\mathrm{APE}_{\mathrm{t}}}\right)}{\log \frac{\left[\mathrm{NO}_{3}^{-}\right]_{0}}{\left[\mathrm{NO}_{3}^{-}\right]_{\mathrm{t}}}}
$$

where $\mathrm{t}$ is the incubation time (days); and $\left[\mathrm{NO}_{3}{ }^{-}\right]_{0}$ and $\left[\mathrm{NO}_{3}{ }^{-}\right]_{\mathrm{t}}$ are the $\mathrm{NO}_{3}{ }^{-}-\mathrm{N}$ concentrations $\left(\mathrm{mg} \mathrm{N} \mathrm{kg}{ }^{-1}\right.$ ) at time 0 and $\mathrm{t}$, respectively. $\mathrm{APE}_{0}$ and $\mathrm{APE}_{\mathrm{t}}$ are the ${ }^{15} \mathrm{~N}$ atom\% excess of $\mathrm{NO}_{3}{ }^{-}$at time 0 and $t$, respectively.

The mean residence times (MRT, days) of $\mathrm{NH}_{4}{ }^{+}-\mathrm{N}$ and $\mathrm{NO}_{3}{ }^{-}-\mathrm{N}$ were calculated according to Corre et al. (2007) [33]. If the MRT value of a certain $\mathrm{N}$ pool is high, it indicates low turnover:

$$
\begin{aligned}
& \mathrm{MRT} \mathrm{NH}_{4}^{+}=\frac{\mathrm{c}\left(\mathrm{NH}_{4}^{+}\right)}{\mathrm{M}_{\mathrm{Norg}}} \\
& \mathrm{MRT} \mathrm{NO}_{3}^{-}=\frac{\mathrm{c}\left(\mathrm{NO}_{3}^{-}\right)}{\mathrm{O}_{\mathrm{NH}}}
\end{aligned}
$$

where $\mathrm{c}\left(\mathrm{NH}_{4}{ }^{+}\right)$and $\mathrm{c}\left(\mathrm{NO}_{3}{ }^{-}\right)$are the initial $\mathrm{NH}_{4}{ }^{+}-\mathrm{N}$ and $\mathrm{NO}_{3}{ }^{-}-\mathrm{N}$ concentrations $\left(\mathrm{mg} \mathrm{N} \mathrm{kg}^{-1}\right)$ in the soils, respectively.

Differences in soil physicochemical properties and $\mathrm{M}_{\mathrm{Norg}}$ and $\mathrm{O}_{\mathrm{NH} 4}$ rates between forest and fruit crop plantation soils were evaluated using analysis of variance followed by Tukey's test at $p<0.05$ significance level. Statistical analyses were performed using IBM SPSS Statistics 24 (IBM Corp., Armonk, NY, USA).

\section{Results}

\subsection{Soil Properties}

SOC, total N, and Ca concentrations, and CEC, WHC, and pH were significantly lower in soils under long-term fruit crop cultivations than in forest soils $(p<0.05)$, with similar trends observed at all three fruit crop sites examined (Table 1). Soil Ca concentrations were significantly and positively correlated with SOC, total N, CEC, WHC, and pH (Table 2). Compared with the forest soils, long-term fruit crop cultivation increased clay but decreased sand content, with significant differences observed between the forest and crop sites at the Jianshui and Guilin sites $(p<0.05)$. There were no significant 
differences in $\mathrm{NH}_{4}{ }^{+}-\mathrm{N}$ concentrations between forest and fruit crop soils across the three study sites $(p>0.05)$, with considerable variations observed in $\mathrm{NO}_{3}{ }^{-}-\mathrm{N}$ concentrations. Although the $\mathrm{NO}_{3}{ }^{-}-\mathrm{N}^{-}$ concentrations in forest soils were significantly lower than the concentrations in soils under citrus and pitaya plantations $(p<0.05)$, there were no significant differences in $\mathrm{NO}_{3}{ }^{-}-\mathrm{N}$ concentrations between forest and "Shatangju" plantation soils. In all the soils studied, inorganic $\mathrm{N}$ was dominated by $\mathrm{NO}_{3}{ }^{-}-\mathrm{N}^{-}$ $\left(\mathrm{NO}_{3}{ }^{-}-\mathrm{N} / \mathrm{NH}_{4}{ }^{+}-\mathrm{N}\right.$ ratios: $\left.1.28-6.47\right)$.

Table 1. Physical and chemical properties of soils from forests and fruit crop plantations in three karst regions.

\begin{tabular}{|c|c|c|c|c|c|c|}
\hline \multirow{2}{*}{ Parameter $^{i}$} & \multicolumn{2}{|c|}{ Jianshui } & \multicolumn{2}{|c|}{ Pingguo } & \multicolumn{2}{|c|}{ Guilin } \\
\hline & Forest & Citrus & Forest & Pitaya & Forest & 'Shatangju' \\
\hline $\mathrm{SOC}\left(\mathrm{g} \mathrm{C} \mathrm{kg}^{-1}\right)$ & $56.8 \pm 5.12 \mathrm{a}^{\mathrm{ii}}$ & $8.75 \pm 1.34 b$ & $142 \pm 92.0 \mathrm{a}$ & $28.5 \pm 2.56 \mathrm{~b}$ & $89.4 \pm 10.8 \mathrm{a}$ & $31.6 \pm 8.82 b$ \\
\hline $\mathrm{TN}\left(\mathrm{gC} \mathrm{kg}^{-1}\right)$ & $4.76 \pm 0.63 a$ & $1.08 \pm 0.08 b$ & $12.5 \pm 6.74 a$ & $3.06 \pm 0.26 b$ & $7.28 \pm 0.75 a$ & $2.77 \pm 0.64 b$ \\
\hline $\mathrm{pH}$ & $7.17 \pm 0.43 a$ & $4.50 \pm 0.05 b$ & $7.20 \pm 0.40 \mathrm{a}$ & $6.00 \pm 0.13 b$ & $7.18 \pm 0.25 a$ & $5.91 \pm 0.25 b$ \\
\hline WHC & $1.11 \pm 0.06 a$ & $0.75 \pm 0.03 b$ & $1.43 \pm 0.29 a$ & $0.76 \pm 0.04 b$ & $1.25 \pm 0.09 a$ & $0.88 \pm 0.04 b$ \\
\hline CEC $\left(\mathrm{cmol} \mathrm{kg}^{-1}\right)$ & $35.9 \pm 3.12 \mathrm{a}$ & $15.2 \pm 0.36$ & $50.4 \pm 17.1 \mathrm{a}$ & $21.1 \pm 0.67 \mathrm{~b}$ & $41.5 \pm 2.79 a$ & $21.7 \pm 2.79 b$ \\
\hline $\mathrm{CaO}(\%)$ & $2.03 \pm 0.55 a$ & $0.27 \pm 0.05 b$ & $4.01 \pm 1.49 \mathrm{a}$ & $0.83 \pm 0.04 b$ & $2.15 \pm 0.22 \mathrm{a}$ & $0.72 \pm 0.17 \mathrm{~b}$ \\
\hline$P\left(\mathrm{~g} \mathrm{~kg}^{-1}\right)$ & $1.47 \pm 0.30 \mathrm{a}$ & $1.36 \pm 0.14 \mathrm{a}$ & $1.10 \pm 0.78 b$ & $3.33 \pm 0.08 a$ & $0.93 \pm 0.09 a$ & $0.69 \pm 0.14 \mathrm{a}$ \\
\hline Clay $(<2 \mu \mathrm{m}, \%)$ & $27.5 \pm 5.60 \mathrm{~b}$ & $42.9 \pm 1.21 \mathrm{a}$ & $34.5 \pm 3.84 \mathrm{a}$ & $39.5 \pm 3.74 a$ & $32.3 \pm 2.49 b$ & $46.0 \pm 1.90 \mathrm{a}$ \\
\hline Silt $(2 \sim 50 \mu \mathrm{m}, \%)$ & $56.2 \pm 3.51 \mathrm{a}$ & $49.3 \pm 1.17 \mathrm{a}$ & $42.1 \pm 5.30 \mathrm{a}$ & $37.5 \pm 2.21 \mathrm{a}$ & $51.4 \pm 2.72 \mathrm{a}$ & $44.0 \pm 0.20 \mathrm{~b}$ \\
\hline Sand (50 2000 $\mu \mathrm{m}, \%)$ & $16.2 \pm 3.67 \mathrm{a}$ & $7.73 \pm 0.30 \mathrm{~b}$ & $23.5 \pm 6.49 a$ & $23.0 \pm 3.97 \mathrm{a}$ & $16.3 \pm 0.30 \mathrm{a}$ & $9.99 \pm 1.74 b$ \\
\hline $\mathrm{NH}_{4}^{+}\left(\mathrm{mg} \mathrm{N} \mathrm{kg}^{-1}\right)$ & $10.2 \pm 1.11 \mathrm{a}$ & $9.31 \pm 1.54 a$ & $7.08 \pm 0.96 a$ & $4.99 \pm 0.35 a$ & $3.38 \pm 1.01 a$ & $6.47 \pm 2.68 \mathrm{a}$ \\
\hline $\mathrm{NO}_{3}{ }^{-}\left(\mathrm{mg} \mathrm{N} \mathrm{kg}^{-1}\right)$ & $13.1 \pm 3.15 b$ & $33.6 \pm 10.1 \mathrm{a}$ & $13.5 \pm 2.99 b$ & $22.5 \pm 2.56 a$ & $21.9 \pm 3.84 \mathrm{a}$ & $24.8 \pm 10.7 \mathrm{a}$ \\
\hline $\mathrm{NO}_{3}{ }^{-} / \mathrm{NH}_{4}{ }^{+}$ & $1.28 \pm 0.18 b$ & $3.72 \pm 1.55 a$ & $1.89 \pm 0.27 b$ & $4.45 \pm 0.59 a$ & $6.47 \pm 1.14 \mathrm{a}$ & $4.24 \pm 2.26 \mathrm{a}$ \\
\hline
\end{tabular}

${ }^{\text {i }}$ SOC, soil organic C; TN, total N; WHC, water holding capacity; CEC, cation exchange capacity. ${ }^{\text {ii }}$ Identical letters indicate no significant differences in the average values in soils from forest and fruit crop plantation in the same region at $p=0.05$. 
Table 2. The relationships between soil properties, $\mathrm{M}_{\mathrm{Norg}}$ and $\mathrm{O}_{\mathrm{NH} 4}$ rates, $\mathrm{MRT} \mathrm{NH}_{4}{ }^{+}$and $\mathrm{MRT} \mathrm{NO}_{3}{ }^{-}(\mathrm{n}=18)$.

\begin{tabular}{|c|c|c|c|c|c|c|c|c|c|c|c|c|c|c|c|}
\hline & $\mathrm{O}_{\mathrm{NH} 4}$ & $\begin{array}{c}\text { MRT } \\
\mathrm{NH}_{4}{ }^{+}\end{array}$ & $\begin{array}{l}\text { MRT } \\
\mathrm{NO}_{3}{ }^{-}\end{array}$ & SOC & TN & $\mathrm{pH}$ & $\mathrm{NH}_{4}{ }^{+}$ & $\mathrm{NO}_{3}{ }^{-}$ & WHC & Clay & Silt & Sand & CEC & $\mathbf{P}$ & $\mathrm{CaO}$ \\
\hline $\mathrm{M}_{\text {Norg }}$ & $0.94 * *$ & $-0.66^{* *}$ & $-0.54 *$ & $0.95^{* *}$ & $0.96^{* *}$ & $0.58 *$ & 0.03 & -0.44 & $0.91^{* *}$ & $-0.54^{*}$ & 0.06 & $0.52 *$ & $0.92 * *$ & -0.04 & $0.95^{* *}$ \\
\hline $\mathrm{O}_{\mathrm{NH} 4}$ & 1 & $-0.71^{* *}$ & $-0.61^{* *}$ & $0.94^{* *}$ & $0.95^{* *}$ & $0.65^{* *}$ & -0.11 & -0.39 & $0.90^{* *}$ & $-0.60^{* *}$ & 0.16 & 0.47 * & $0.94^{* *}$ & 0.00 & $0.93^{* *}$ \\
\hline $\mathrm{MRT} \mathrm{NH}_{4}{ }^{+}$ & & 1 & $0.71^{* *}$ & $-0.64^{* *}$ & $-0.65^{* *}$ & $-0.80^{* *}$ & 0.41 & $0.54^{*}$ & $-0.69^{* *}$ & $0.69^{* *}$ & 0.00 & $-0.73^{* *}$ & $-0.73^{* *}$ & -0.16 & $-0.70^{* *}$ \\
\hline $\mathrm{MRT} \mathrm{NO}_{3}{ }^{-}$ & & & 1 & $-0.51 *$ & $-0.53 *$ & -0.79 ** & 0.13 & $0.79 * *$ & $-0.60 *$ & $0.67^{* *}$ & -0.07 & $-0.64 *$ & $-0.63^{* *}$ & -0.15 & -0.61 * \\
\hline $\mathrm{SOC}$ & & & & 1 & $0.99^{* *}$ & $0.59 *$ & -0.13 & -0.38 & $0.94^{* *}$ & $-0.49 *$ & 0.08 & 0.43 & $0.96^{* *}$ & -0.10 & $0.93^{* *}$ \\
\hline $\mathrm{TN}$ & & & & & 1 & $0.60^{*}$ & -0.13 & -0.40 & $0.93^{* *}$ & -0.47 & 0.02 & 0.48 * & $0.95^{* *}$ & -0.08 & $0.95^{* *}$ \\
\hline $\mathrm{pH}$ & & & & & & 1 & -0.21 & $-0.71^{* *}$ & $0.72 * *$ & $-0.66^{* *}$ & 0.18 & $0.52 *$ & $0.76^{* *}$ & -0.17 & $0.73^{* *}$ \\
\hline $\mathrm{NH}_{4}^{+}$ & & & & & & & 1 & 0.04 & -0.08 & -0.04 & 0.35 & -0.31 & -0.09 & -0.07 & -0.03 \\
\hline $\mathrm{NO}_{3}^{-}$ & & & & & & & & 1 & -0.50 * & $0.60 *$ & -0.07 & $-0.56^{*}$ & $-0.50 *$ & 0.05 & $-0.52 *$ \\
\hline WHC & & & & & & & & & 1 & $-0.60 *$ & 0.23 & 0.40 & $0.98^{* *}$ & -0.31 & $0.93^{* *}$ \\
\hline Clay & & & & & & & & & & 1 & $-0.54 *$ & -0.51 * & $-0.63 *$ & -0.02 & -0.53 * \\
\hline Silt & & & & & & & & & & & 1 & -0.45 & 0.20 & -0.38 & 0.10 \\
\hline Sand & & & & & & & & & & & & 1 & 0.46 & 0.40 & 0.46 \\
\hline CEC & & & & & & & & & & & & & 1 & -0.17 & $0.95^{* *}$ \\
\hline $\mathrm{P}$ & & & & & & & & & & & & & & 1 & -0.13 \\
\hline
\end{tabular}

SOC, soil organic C; TN, total N; WHC, water holding capacity; CEC, cation exchange capacity; $\mathrm{M}_{\mathrm{Norg}}$, mineralization (the conversion of organic $\mathrm{N}$ to $\mathrm{NH}_{4}{ }^{+}$); $\mathrm{O}_{\mathrm{NH} 4}$, nitrification (the oxidation of $\mathrm{NH}_{4}{ }^{+}$to $\mathrm{NO}_{3}{ }^{-}$); $\mathrm{MRT} \mathrm{NH}_{4}{ }^{+}$, the mean residence time of $\mathrm{NH}_{4}{ }^{+}$; $\mathrm{MRT} \mathrm{NO}_{3}{ }^{-}$, the mean residence time of $\mathrm{NO}_{3}{ }^{-} .{ }^{*}, p<0.05 ;{ }^{* *}, p<0.01$. 


\subsection{N Cycling Rate}

The rate of organic $\mathrm{N}$ mineralization into $\mathrm{NH}_{4}{ }^{+}\left(\mathrm{M}_{\mathrm{Norg}}\right)$ ranged from $2.85 \mathrm{mg} \mathrm{N} \mathrm{kg}^{-1} \mathrm{~d}^{-1}$ to $6.49 \mathrm{mg} \mathrm{N} \mathrm{kg}^{-1} \mathrm{~d}^{-1}$ in forest soils (Figure 2). The conversion of forest lands to long-term fruit crop cultivation systems decreased $\mathrm{M}_{\mathrm{Norg}}$ significantly to $0.61-1.34 \mathrm{mg} \mathrm{N} \mathrm{kg}^{-1} \mathrm{~d}^{-1}$ across the three study sites. Compared to forest lands (8.17-15.5 $\left.\mathrm{mg} \mathrm{N} \mathrm{kg}^{-1} \mathrm{~d}^{-1}\right)$, long-term fruit crop cultivation significantly decreased the rate of oxidation of $\mathrm{NH}_{4}{ }^{+}-\mathrm{N}_{\text {into }} \mathrm{NO}_{3}{ }^{-}-\mathrm{N}\left(\mathrm{O}_{\mathrm{NH} 4}\right)$ to $1.95-5.07 \mathrm{mg} \mathrm{N} \mathrm{kg}^{-1} \mathrm{~d}^{-1}$ (Figure 2). In addition, there were significant and positive correlations between $\mathrm{M}_{\mathrm{Norg}}$ and $\mathrm{O}_{\mathrm{NH} 4}$ rates. The mean residence times of $\mathrm{NH}_{4}{ }^{-}-\mathrm{N}$ and $\mathrm{NO}_{3}{ }^{-}-\mathrm{N}$ were significantly lower in soil under forests (1.18-3.66 d and $0.97-2.03 \mathrm{~d}$, respectively) than those under long-term fruit crop cultivation (3.91-11.8 $\mathrm{d}$ and 4.39-17.5 d, respectively) $(p<0.05)$. The correlation analyses showed that $\mathrm{M}_{\mathrm{Norg}}$ and $\mathrm{O}_{\mathrm{NH} 4}$ were positively correlated with SOC, total $\mathrm{N}$ and Ca concentrations, and CEC, WHC, and sand content, but were negatively correlated with clay content (Table 2). Conversely, such soil properties were negatively correlated with the mean residence times of $\mathrm{NH}_{4}{ }^{+}-\mathrm{N}$ and $\mathrm{NO}_{3}{ }^{-}-\mathrm{N}$ (Figure 3).
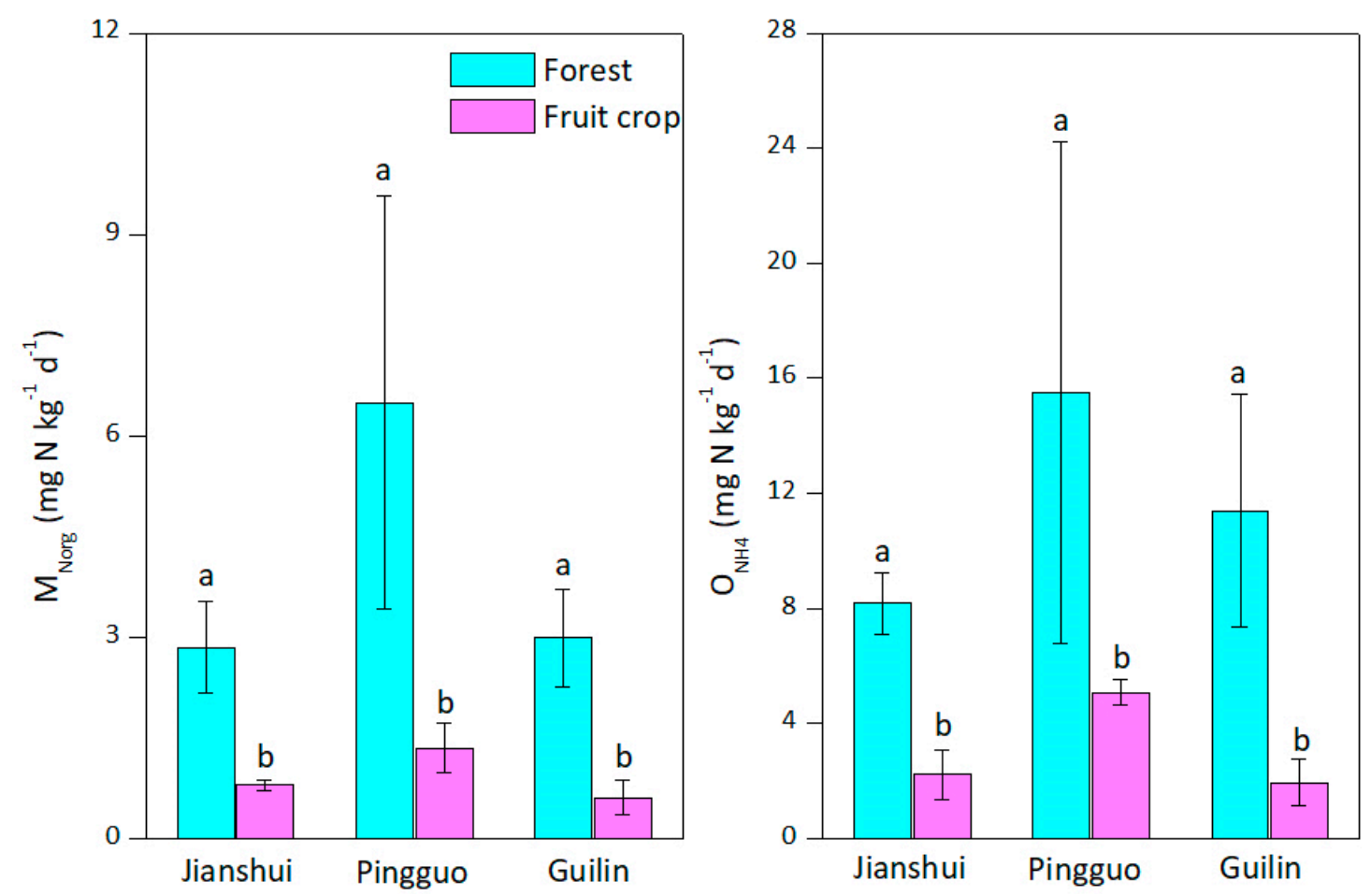

Figure 2. $\mathrm{M}_{\mathrm{Norg}}$ and $\mathrm{O}_{\mathrm{NH} 4}$ rates in soils sampled from Jianshui (forest vs. citrus), Pingguo (forest vs. pitaya), and Guilin (forest vs. Shatangju) regions. Different letters for $\mathrm{M}_{\mathrm{Norg}}$ or $\mathrm{O}_{\mathrm{NH} 4}$ indicate significant differences $(p<0.05)$ between forest and fruit crop plantation in the same region. $\mathrm{M}_{\text {Norg }}$, the mineralization of organic $\mathrm{N}$ to $\mathrm{NH}_{4}{ }^{+} ; \mathrm{O}_{\mathrm{NH} 4}$, the oxidation of $\mathrm{NH}_{4}{ }^{+}$to $\mathrm{NO}_{3}{ }^{-}$. 

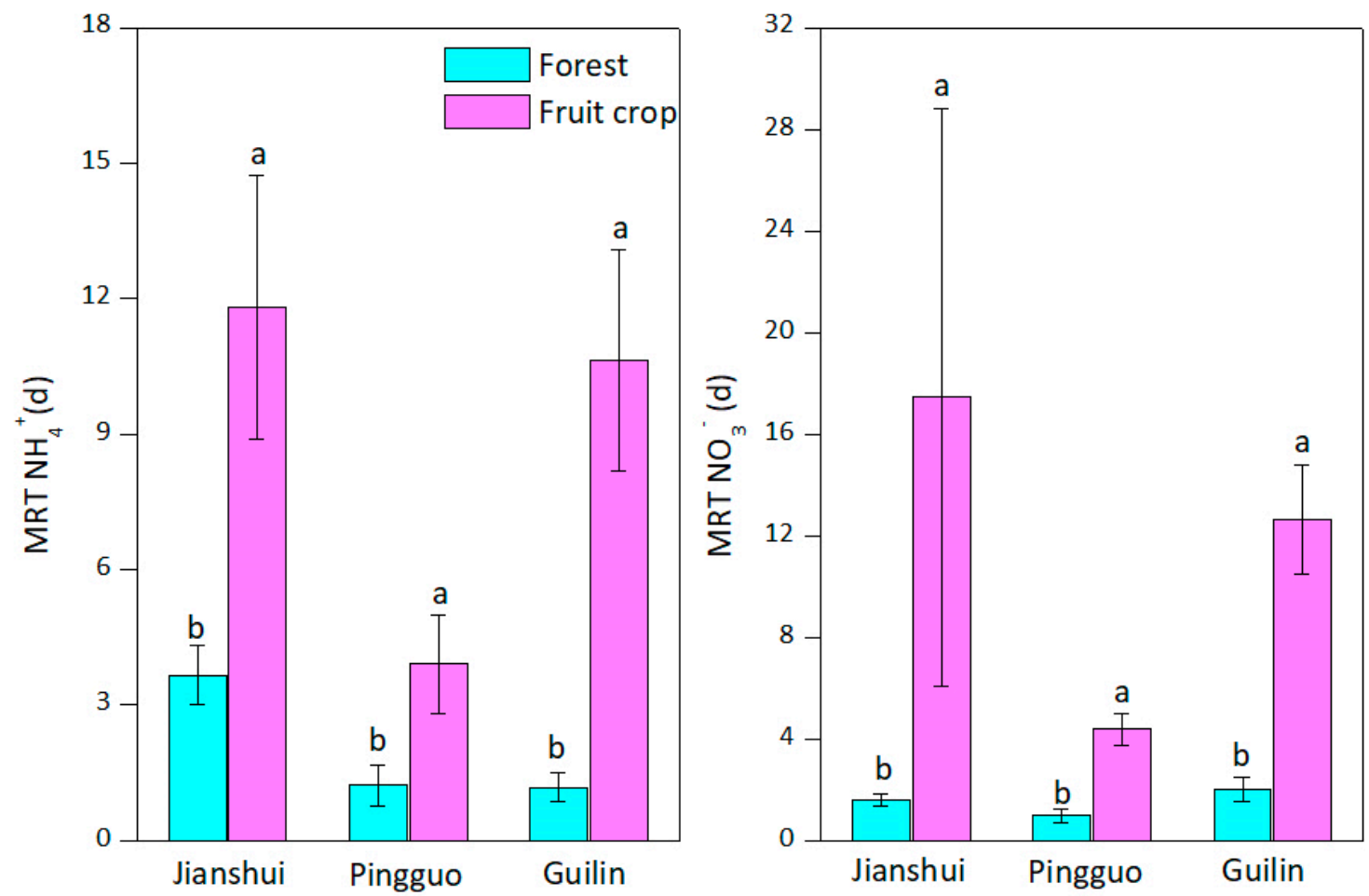

Figure 3. Mean residence time of $\mathrm{NH}_{4}{ }^{+}\left(\mathrm{MRT} \mathrm{NH}_{4}{ }^{+}\right)$and $\mathrm{NO}_{3}{ }^{2212}\left(\mathrm{MRT} \mathrm{NO}_{3}{ }^{-}\right)$in soils sampled from Jianshui (forest vs. citrus), Pingguo (forest vs. pitaya), and Guilin (forest vs. Shatangju) regions. Different letters for MRT $\mathrm{NH}_{4}{ }^{+}$and $\mathrm{MRT} \mathrm{NO}_{3}{ }^{-}$indicate significant differences $(p<0.05)$ between forest and fruit crop plantation in the same region.

\section{Discussion}

In the present study, the mineralization rates in calcareous soils in forests in karst regions (2.85-6.49 $\mathrm{mg} \mathrm{N} \mathrm{kg}^{-1} \mathrm{~d}^{-1}$ ) were comparable to those measured in subtropical and tropical non-karst regions (1.52-15.0 $\mathrm{mg} \mathrm{N} \mathrm{kg}^{-1} \mathrm{~d}^{-1}$ ) [16,34-36]. The results showed that long-term fruit crop cultivation decreased mineralization rate significantly, indicating decreased soil inorganic $\mathrm{N}$ supply capacity. Previous studies have reported that SOM content is the key factor influencing mineralization rate $[16,18,25]$. Indeed, mineralization rate was significantly positively correlated with SOC and total N concentrations in the present study, further confirming the key role of SOM content in mineralization. High Ca in calcareous soils in karst regions can bind with SOM to promote SOM accumulation, which could facilitate the maintenance of SOC concentrations at high levels in forestlands $[10,26,27]$. When forests on sloped lands are reclaimed for the cultivation of fruit crops, the introduced management practices (e.g., tillage, fertilization) as well as mulch reduction could reduce SOM content significantly by accelerating SOM decomposition and minimizing the protection Ca confers on organic matter [19,37], which was supported by the significant and positive correlations among $\mathrm{Ca}, \mathrm{SOC}$, and total $\mathrm{N}$ concentrations (Table 2). The decline in SOM may be the main reason for the decreased mineralization rate in soil under long-term fruit crop cultivation.

In the present study, the nitrification rates $\left(8.17-15.5 \mathrm{mg} \mathrm{N} \mathrm{kg}^{-1} \mathrm{~d}^{-1}\right.$, on average: $\left.11.7 \mathrm{mg} \mathrm{N} \mathrm{kg}^{-1} \mathrm{~d}^{-1}\right)$ in calcareous soil under forests were higher than rates previously observed and based on similar methods in highly weathered soils developed from granite or basalt in natural forests in tropical and subtropical regions (0.30-3.80 $\left.\mathrm{mg} \mathrm{N} \mathrm{kg}^{-1} \mathrm{~d}^{-1}\right)[16,18,34,35,38]$. Such differences in nitrification rates between calcareous soil and other soils may be mainly attributed to $\mathrm{pH}$. Previous studies have reported that nitrification rate is significantly positively correlated with $\mathrm{pH}$ at the regional scale $[16,35,38]$. The relatively high organic matter content in calcareous soils under forests could promote macroaggregation, and, in turn, facilitate the diffusion of $\mathrm{O}_{2}[39]$, which can increase the 
activity and abundance of $\mathrm{AOB}[29,40]$, and stimulate the oxidation of $\mathrm{NH}_{4}{ }^{+}-\mathrm{N}$ into $\mathrm{NO}_{3}{ }^{-}-\mathrm{N}$ under high $\mathrm{pH}$ conditions. This may explain why higher nitrification rates were observed in calcareous soil ( $\mathrm{pH}$ 6.69-7.65) than other soils under forests in non-karst regions. Due to the rapid oxidation of $\mathrm{NH}_{4}{ }^{+}-\mathrm{N}$ into $\mathrm{NO}_{3}{ }^{-}-\mathrm{N}$, inorganic $\mathrm{N}$ was dominated by $\mathrm{NO}_{3}{ }^{-}-\mathrm{N}$ rather than $\mathrm{NH}_{4}{ }^{+}-\mathrm{N}$ in calcareous soils under forests in the present study.

Generally, the application of chemical and organic fertilizers can stimulate the activity and increase the abundance of $\mathrm{AOB}$, and, in turn, increase the oxidation of $\mathrm{NH}_{4}{ }^{+}-\mathrm{N}[28,29]$. However, this was not the case in the present study. Long-term cultivation of fruit crops significantly decreased nitrification rate to $1.95-5.07 \mathrm{mg} \mathrm{kg}^{-1} \mathrm{~d}^{-1}$ (on average: $3.08 \mathrm{mg} \mathrm{N} \mathrm{kg}^{-1} \mathrm{~d}^{-1}$ ). The significant correlations between nitrification rate, clay, and sand content indicate that soil texture (Table 2) may be the key factor affecting nitrification rate in karst regions. When forestlands are reclaimed and planted with fruit crops, SOM loss can lead to the deterioration of soil structure, and soil becomes predominantly clayey $[3,30]$. Indeed, soil clay content increased following the long-term cultivation of fruit crops after conversion from forestland (Table 1). Poor permeability of heavy clay soil can inhibit the diffusion of oxygen and hinder the oxidation of $\mathrm{NH}_{4}{ }^{+}-\mathrm{N}$ into $\mathrm{NO}_{3}{ }^{-}-\mathrm{N}$, even when $\mathrm{N}$ fertilizer is applied [41]. In addition, the degradation of soil quality after long-term agricultural cultivation can decrease the activities of $\mathrm{N}$ functional microorganisms [8,10], which may lower nitrification rates. Overall, these findings suggest that long-term cultivation of fruit crops can substantially decrease inorganic $\mathrm{N}$ supply capacity through the inhibition of mineralization and nitrification in calcareous soils in karst regions, which is consistent with our first hypothesis.

Although long-term fruit crop cultivation significantly decreased mineralization and nitrification rates, the mean residence times of $\mathrm{NH}_{4}{ }^{+}-\mathrm{N}_{\text {and }} \mathrm{NO}_{3}{ }^{-}-\mathrm{N}$ increased considerably, which is consistent with our second hypothesis that long-term fruit crop cultivation decreases the turnover of inorganic $\mathrm{N}$ in karst regions. In such a case, high inorganic $\mathrm{N}$ from $\mathrm{N}$ fertilizer inputs can be retained in soil, which may increase $\mathrm{N}$ loss risks while decreasing $\mathrm{N}$ utilization efficiency. Therefore, soil $\mathrm{N}$ cycling processes need to be adjusted to improve $\mathrm{N}$ supply and promote inorganic $\mathrm{N}$ turnover under long-term fruit crop cultivation systems in karst regions.

\section{Conclusions}

Long-term cultivation of fruit crops significantly decreased mineralization and nitrification rates but increased the mean $\mathrm{NH}_{4}{ }^{+}-\mathrm{N}$ and $\mathrm{NO}_{3}{ }^{-}-\mathrm{N}$ resident times in the karst region, indicating declines in inorganic $\mathrm{N}$ supply capacity and turnover. Such shifts in $\mathrm{N}$ cycling are primarily attributed to decreased SOM and increased clay content. The appropriate organic $\mathrm{N}$ fertilization practices in the karst region should be investigated further, which could facilitate efforts to improve soil quality and inorganic $\mathrm{N}$ supply and turnover under such unique agroecosystems. Noticeably, only soils were sampled in this study, but the coupled interactions between soil $\mathrm{N}$ supply and plant $\mathrm{N}$ utilization efficiency were not directly determined, which need to be systematically considered in future research to more guide $\mathrm{N}$ fertilizer application in crop cultivation systems in the karst region.

Author Contributions: Conceptualization, Z.S. and T.Z.; investigation, Z.S., Z.Y. and C.Z.; formal analysis, H.Y. and C.Z.; original draft preparation, Z.S. and T.Z.; writing-review and editing, Z.S. and T.Z. All authors have read and agreed to the published version of the manuscript.

Funding: This work was funded by grants from The National Key Research and Development Program of China (2016YFC0502503), CAGS Research Fund (YYWF 2020003), Guangxi Natural Science Foundation of China (2018GXNSFAA281026), and Guangxi Key Research and Development Program (GuikeAB110004).

Conflicts of Interest: The authors declare no conflict of interest. 


\section{References}

1. Zhang, C.H.; Qi, X.K.; Wang, K.L.; Zhang, M.Y.; Yue, Y.M. The application of geospatial techniques in monitoring karst vegetation recovery in southwest China: A review. Prog. Phys. Geog. 2017, 41, 450-477. [CrossRef]

2. Tong, X.W.; Brandt, M.; Yue, Y.M.; Horion, S.; Wang, K.L.; Keersmaecker, W.D.; Tian, F.; Schurgers, G.; Xiao, X.M.; Luo, Y.Q.; et al. Increased vegetation growth and carbon stock in China karst via ecological engineering. Nat. Sustain. 2018, 1, 44-50. [CrossRef]

3. Wang, K.L.; Zhang, C.H.; Chen, H.S.; Yue, Y.M.; Zhang, W.; Zhang, M.Y.; Qi, X.K.; Fu, Z.Y. Karst landscapes of China: Patterns, ecosystem processes and services. Landsc. Ecol. 2019, 34, 2743-2763. [CrossRef]

4. Jiang, Z.H.; Liu, H.Y.; Wang, H.Y.; Peng, J.; Meersmans, J.; Green, S.M.; Quine, T.A.; Wu, X.C.; Song, Z.L. Bedrock geochemistry influences vegetation growth by regulating the regolith water holding capacity. Nat. Commun. 2020, 11, 2392. [CrossRef] [PubMed]

5. Wang, S.J.; Liu, Q.M.; Zhang, D.F. Karst rocky desertification in southwestern China: Geomorphology, landuse, impact and rehabilitation. Land Degrad. Dev. 2004, 15, 115-121. [CrossRef]

6. Hartmann, A.; Goldscheider, N.; Wagener, T.; Weiler, J.L.M. Karst water resources in a changing world: Review of hydrological modeling approaches. Rev. Geophys. 2014, 52, 218-242. [CrossRef]

7. Jiang, Z.C.; Lian, Y.Q.; Qin, X.Q. Rocky desertification in Southwest China: Impacts, causes, and restoration. Earth Sci. Rev. 2014, 132, 1-12. [CrossRef]

8. Guillaume, T.; Holtkamp, A.M.; Muhammad, D.; Brümmer, B.; Kuzyakov, Y. Soil degradation in oil palm and rubber plantations under land resource scarcity. Agr. Ecosyst. Environ. 2016, 232, 110-118. [CrossRef]

9. Kurniawan, S.; Corre, M.D.; Matson, A.L.; Schulte-Bisping, H.; Utami, S.R.; van Straaten, O.; Veldkamp, E. Conversion of tropical forests to smallholder rubber and oil palm plantations impacts nutrient leaching losses and nutrient retention efficiency in highly weathered soils. Biogeosciences 2018, 15, 5131-5154. [CrossRef]

10. Garousi, F.; Zhijie Shan, Z.J.; Ni, K.; Yang, H.; Shan, J.; Cao, J.H.; Jiang, Z.C.; Yang, J.L.; Zhu, T.B.; Müller, C. Decreased inorganic $\mathrm{N}$ supply capacity and turnover in calcareous soil under degraded rubber plantation in the tropical karst region. Geoderma 2021, 381, 114754. [CrossRef]

11. Vitousek, P.M.; Howarth, R.W. Nitrogen limitation on land and in the sea: How can it occur? Biogeochemistry 1991, 13, 87-115. [CrossRef]

12. LeBauer, D.S.; Treseder, K.K. Nitrogen limitation of net primary productivity in terrestrial ecosystems is globally distributed. Ecology 2008, 89, 371-379. [CrossRef] [PubMed]

13. Schimel, J.P.; Bennett, J. Nitrogen mineralization: Challenges of a changing paradigm. Ecology 2004, 85, 591-602. [CrossRef]

14. Hobbie, E.A.; Högberg, P. Nitrogen isotopes link mycorrhizal fungi and plants to nitrogen dynamics. New Phytol. 2012, 196, 367-382. [CrossRef]

15. Zhu, T.B.; Zhang, J.B.; Meng, T.Z.; Zhang, Y.C.; Yang, J.J.; Müller, C.; Cai, Z.C. Tea plantation destroys soil retention of $\mathrm{NO}_{3}{ }^{-}$and increases $\mathrm{N}_{2} \mathrm{O}$ emissions in subtropical China. Soil Biol. Biochem. 2014, 73, 106-114. [CrossRef]

16. Xie, Y.; Yang, L.; Zhu, T.B.; Yang, H.; Zhang, J.B.; Yang, J.L.; Cao, J.H.; Bai, B.; Jiang, Z.C.; Liang, Y.M.; et al. Rapid recovery of nitrogen retention capacity in a subtropical acidic soil following afforestation. Soil Biol. Biochem. 2018, 120, 171-180. [CrossRef]

17. Rütting, T.; Clough, T.J.; Müller, C.; Lieffering, M.; Newton, P.C.D. Ten years of elevated atmospheric carbon dioxide alters soil nitrogen transformations in a sheep-grazed pasture. Global Change Biol. 2010, 16, 2530-2542. [CrossRef]

18. Zhu, T.B.; Meng, T.Z.; Zhang, J.B.; Yin, Y.F.; Cai, Z.C.; Yang, W.Y.; Zhong, W.H. Nitrogen mineralization, immobilization turnover, heterotrophic nitrification, and microbial groups in acid forest soils of subtropical China. Biol. Fert. Soils 2013, 49, 323-331. [CrossRef]

19. Allen, K.; Corre, M.D.; Tjoa, A.; Veldkamp, E. Soil nitrogen-cycling responses to conversion of lowland forests to oil palm and rubber plantations in Sumatra, Indonesia. PLoS ONE 2015, 10, e0133325. [CrossRef]

20. Portier, E.; Silver, W.L.; Yang, W.H. Invasive perennial forb effects on gross soil nitrogen cycling and nitrous oxide fluxes depend on phenology. Ecology 2019, 100, e02716. [CrossRef]

21. Zhu, T.B.; Zeng, S.M.; Qin, H.L.; Zhou, K.X.; Lan, F.N.; Yang, H.; Huang, F.; Cao, J.H.; Müller, C. Low nitrate retention capacity in calcareous soil under woodland in the karst region of southwestern China. Soil Biol. Biochem. 2016, 97, 99-101. [CrossRef] 
22. Song, M.; He, T.G.; Chen, H.; Wang, K.L.; Li, D.J. Dynamics of soil gross nitrogen transformations during post-agricultural succession in a subtropical karst region. Geoderma 2019, 341, 1-9. [CrossRef]

23. Bárcenas-Moreno, G.; Rousk, J.; Bååth, E. Fungal and bacterial recolonisation of acid and alkaline forest soils following artificial heat treatments. Soil Biol. Biochem. 2011, 43, 1023-1033. [CrossRef]

24. Chen, H.; Li, D.J.; Xiao, K.C.; Wang, K.L. Soil microbial processes and resource limitation in karst and non-karst forests. Funct. Ecol. 2018, 32, 1400-1409. [CrossRef]

25. Booth, M.S.; Stark, J.M.; Rastetter, E. Controls on nitrogen cycling in terrestrial ecosystems: A synthetic analysis of literature data. Ecol. Monogr. 2005, 75, 139-157. [CrossRef]

26. Yang, L.Q.; Luo, P.; Wen, L.; Li, D.J. Soil organic carbon accumulation during post-agricultural succession in a karst area, southwest China. Sci. Rep. 2016, 6, 37118. [CrossRef] [PubMed]

27. Rowley, M.C.; Grand, S.; Verrecchia, É.P. Calcium-mediated stabilization of soil organic carbon. Biogeochemistry 2018, 137, 27-49. [CrossRef]

28. Chu, H.Y.; Fujii, T.; Morimoto, S.; Lin, X.G.; Yagi, K. Population size and specific nitrification potential of soil ammonia-oxidizing bacteria under long-term fertilizer management. Soil Biol. Biochem. 2008, 40, 1960-1963. [CrossRef]

29. Norton, J.; Ouyang, Y. Controls and adaptive management of nitrification in agricultural soils. Front. Microbiol. 2019, 10, 1931. [CrossRef]

30. Silva, M.B.; dos Anjos, L.H.C.; Pereira, M.G.; Schiavo, J.A.; Cooper, M.; de Souza Cavassani, R. Soils in the karst landscape of Bodoquena plateau in cerrado region of Brazil. Catena 2017, 154, 107-117. [CrossRef]

31. Ross, D.S.; Ketterings, Q. Recommended Methods for Determining Soil Cation Exchange Capacity. In Recommended Soil Testing Procedures for the Northeastern United States; College of Agriculture, University of Delaware: Newark, NJ, USA, 1995.

32. Kirkham, D.; Bartholomew, W.V. Equations for following nutrient transformations in soil utilizing tracer data. Soil Sci. Soc. Am. Proc. 1954, 18, 33-34. [CrossRef]

33. Corre, M.D.; Brumme, R.; Veldkamp, E.; Beese, F.O. Changes in nitrogen cycling and retention processes in soils under spruce forests along a nitrogen enrichment gradient in Germany. Global Change Biol. 2007, 13, 1509-1527. [CrossRef]

34. Sotta, E.D.; Corre, M.D.; Veldkamp, E. Differing N status and n retention processes of soils under old-growth lowland forest in Eastern Amazonia, Caxiuan, Brazil. Soil Biol. Biochem. 2008, 40, 740-750. [CrossRef]

35. Zhang, J.B.; Cai, Z.C.; Zhu, T.B.; Yang, W.Y.; Müller, C. Mechanisms for the retention of inorganic N in acidic forest soils of southern China. Sci. Rep. 2013, 3, 2342. [CrossRef]

36. Ueda, M.U.; Kachina, P.; Marod, D.; Nakashizuka, T.; Kurokawa, H. Soil properties and gross nitrogen dynamics in old growth and secondary forest in four types of tropical forest in Thailand. For. Ecol. Manag. 2017, 398, 130-139. [CrossRef]

37. Liu, X.; Zhang, W.; Wu, M.; Ye, Y.Y.; Wang, K.L.; Li, D.J. Changes in soil nitrogen stocks following vegetation restoration in a typical karst catchment. Land Degrad. Dev. 2019, 30, 60-72. [CrossRef]

38. Zhang, J.B.; Zhu, T.B.; Cai, Z.C.; Müller, C. Nitrogen cycling in forest soils across climate gradients in Eastern China. Plant. Soil 2011, 342, 419-432. [CrossRef]

39. Mariotte, P.; Mehrabi, Z.; Bezemer, T.M.; Deyn, G.B.D.; Kardol, P. Plant-soil feedback: Bridging natural and agricultural sciences. Trends Ecol. Evol. 2018, 33, 129-142. [CrossRef]

40. Nicol, G.W.; Leininger, S.; Schleper, C.; Prosser, J.I. The influence of soil pH on the diversity, abundance and transcriptional activity of ammonia oxidizing archaea and bacteria. Environ. Microbiol. 2008, 10, 2966-2978. [CrossRef]

41. Nawaz, M.F.; Bourrié, G.; Trolard, F. Soil compaction impact and modelling. A review. Agron. Sustain. Dev. 2013, 33, 291-309. [CrossRef]

Publisher's Note: MDPI stays neutral with regard to jurisdictional claims in published maps and institutional affiliations. 